\title{
Correction: Preclinical amyloid pathology biomarker positivity: effects on tau pathology and neurodegeneration
}

\author{
K. Höglund ${ }^{1,2}$, S. Kern ${ }^{1,3}$, A. Zettergren ${ }^{1,3}$, A. Börjesson-Hansson ${ }^{1,3}$, H. Zetterberg ${ }^{1,4}$, I. Skoog ${ }^{1,3}$ and K. Blennow ${ }^{1}$
}

\section{Correction to: Translational Psychiatry; https://doi.org/10.1038/tp.2016.252; published online 10 January 2017.}

The Article was originally published under a CC BY-NCND 4.0 license, but has now been made available under a
CC BY 4.0 license. The PDF and HTML versions of the Article have not been corrected.

Published online: 19 November 2018

Correspondence: K Höglund (kina.hoglund@neuro.gu.se)

${ }^{1}$ Clinical Neurochemistry Laboratory, Institute of Neuroscience and Physiology, Department of Psychiatry and Neurochemistry, The Sahlgrenska Academy,

Centre for ageing and Health, AgeCap, University of Gothenburg, Sahlgrenska University Hospital, Mölndal, Sweden

${ }^{2}$ Department of Neurobiology, Care Sciences and Society, Center for Alzheimer Disease Research, Neurogeriatrics Division, Karolinska Institutet, Novum, Stockholm, Sweden

${ }^{3}$ Department of Molecular Neuroscience, UCL Institute of Neurology, Queen Square, London, UK

${ }^{4}$ Neuropsychiatric Epidemiology Unit, Institute of Neuroscience and Physiology, Department of Psychiatry and Neurochemistry, The Sahlgrenska Academy, Centre for Ageing and Health, AgeCap, University of Gothenburg, Mölndal, Sweden

These authors contributed equally: K Höglund, S Kern

(ㅇ The Author(s) 2019

(c) (i) Open Access This article is licensed under a Creative Commons Attribution 4.0 International License, which permits use, sharing, adaptation, distribution and reproduction in any medium or format, as long as you give appropriate credit to the original author(s) and the source, provide a link to the Creative Commons license, and indicate if changes were made. The images or other third party material in this article are included in the article's Creative Commons license, unless indicated otherwise in a credit line to the material. If material is not included in the article's Creative Commons license and your intended use is not permitted by statutory regulation or exceeds the permitted use, you will need to obtain permission directly from the copyright holder. To view a copy of this license, visit http://creativecommons.org/licenses/by/4.0/. 